\title{
RADIATION EXPOSURE OF THE ARMY OF THE FR YUGOSLAVIA IN KOSOVO AND METOHIA DURING THE NATO AGGRESSION OF 1999
}

\author{
Mirjana N. Anđelković-Lukić \\ Military Technical Institute, Belgrade, Republic of Serbia; \\ Government of the Republic of Serbia, Interagency Coordination Body, \\ Belgrade, Republic of Serbia, \\ e-mail: mirjana.andjelkovic.lukic45@gmail.com, \\ ORCIDiD: (i)https://orcid.org/0000-0002-5076-4901
}

DOI: 10.5937/vojtehg68-25636; https://doi.org/10.5937/vojtehg68-25636

FIELD: Chemical Technology

ARTICLE TYPE: Review Paper

ARTICLE LANGUAGE: English

\begin{abstract}
:
Introduction/purpose: The paper indicates the radiation doses the military personnel of the Federal Republic of Yugoslavia were exposed to, and in particular the military personnel of the motorized brigades in the territory of Kosovo and Metohia on the Albanian-Yugoslav border.
\end{abstract}

Methods: Gammaspectrometry measurements have confirmed that round penetrators contained depleted uranium, and the presence of alpha, beta and gamma radiation was determined by the method of dosimetric measurement.

Results: The use of ammunition with ${ }^{238} \mathrm{U}$ depleted uranium, with added plutonium, pollutes the environment, water, and soil in the long term, causing various disorders and diseases, primarily malignant ones. The radioactivity of ${ }^{239} \mathrm{Pu}$, compared to its toxicity, is several thousand times higher and the inhalation of plutonium dust is harmful and causes cancer. Uranium is a pyrophoric metal, toxic, radioactive and easy to ignite. Its oxides are toxic and partially soluble in water. After ignition, the round releases radioactive aerosol particles which burn in contact with the air causing short or long term damage wheninhaled. In Kosovo and Metohia, a large amount of radioactivity was measured during the NATO aggression against the FR Yugoslavia. In Metohia, radioactivity was 1,100 times that of natural background radiation.

Conclusion: During the war, the Army of the FR Yugoslavia was exposed to high radioactive doses, so that among the members of the army after 
the war there was an increased incidence of various malignancies, many of them lethal.

Keywords: chemical warfare, depleted uranium ammunition, increased radioactivity, chemotoxicity, plutonium, exposure of the Army of the FR Yugoslavia to radiation, disease, malignancy.

\section{Introduction}

The 78-day NATO aggression on the Federal Republic of Yugoslavia in March 1999 represents one of the most shameful pages in the history of international relations and the modern-day civilization of the second half of the 20th century. It is a crime against peace, human health and the environment. It caused an increase in various malignancies, difficulty in conceiving, sterility, the number of miscarriages, thyroid diseases, and an increased occurrence of asthma in children as well as in the elderly.

The use of ammunition with depleted uranium caused a large increase in various malignancies after the war, and thus the number of deaths in the FR Yugoslavia during the aggression can be added to the number of deaths which is increasing daily, since in most cases they died from radiation. During the 1999 aggression against the Federal Republic of Yugoslavia, enormous material damage and irreparable loss of life were inflicted on people and the eco system. Besides the destruction of cities and infrastructure by various missile types, a great tragedy was caused by depleted uranium (DU) rounds (uranium depleted in ${ }^{235} \mathrm{U}$ isotope), fired from Gatling-type guns ofthe A-10 aircraft.

The exposure of the Army of the FR Yugoslavia and the civilian population to radiation was particularly increased in the territory of Kosovo and Metohia and southeastern Serbia, the surroundings of Vranje and the near-by villages. However, the radiation from Kosovo and Metohia also reached the surrounding countries, so Bulgaria and Greece reported increased radioactivity in their countries. Radioactivity from Kosovo and Metohia spread to other parts of the country, so the incidence of various tumors throughout Serbia has increased.

By the decision of the Government of the Republic of Serbia, on June 12, 2018, the Commission for Determining the Consequences of NATO Bombing was formed in order to establish all relevant facts and inform the public about it. 


\section{Number of uranium depleted rounds fired on the Federal Republic of Yugoslavia}

The countries that directly attacked FR Yugoslavia were 228 times larger than the FR Yugoslavia, had 67 times bigger population, their economic potential exceeded that of Yugoslavia by 679 times, and they were 37 times more technically superior. The exact number of fired DU rounds will never be known, because NATO, and above all the USA, keep this information secret; they do not want to admit how many missiles they fired, as it would show that they had genocidal intentagainst the Serbian (but also the Albanian) people. There are three reports on the amount of depleted uranium ammunitionused during the 1999 aggression on the FR Yugoslavia:

- The first report is the one compiled by NATO, which states the number of 31,000 missiles.

- The second is the report of the Army of the FR Yugoslavia, according to which about 50,000 pieces of DU ammunition were fired, and

- The third is from Russian sources which estimate that about 90,000 DU missiles were fired in the territory of FR Yugoslavia.

Most DU rounds targeted the territories of Kosovo and Metohia and southern Serbia.

However, retired Major General Božidar Delić, on the basis of his observations while commanding the 549th Motorized Brigade in Kosovo and Metohia, then in the rank of colonel, believes that the number of used DU rounds is much higher. According to the General's estimate, 225 tons of depleted uranium were dropped on the territory of Kosovo and Metohia. The Army of the FR Yugoslavia has data about approximately 15 tons, which is almost 15 times less than the General's estimation (Delić, 2019). The 549th Brigade, commanded by then-colonel Božidar Delić, and the 125th Motorized Brigade, commanded by thencolonel Dragan Živanović, were located on the Yugoslav-Albanian border. The 549th Motorized Brigade was stationed in Prizren and within its area of responsibility was the territory of Paštrik, and in the area of responsibility of the 125th Motorized Brigade, stationed in Kosovska Mitrovica, was the territory of Košare.

The data collected by the FRY Army and the NATO data can be summarized as follows: a total of 112 air strikes with DU ammunition occurred at 91 locations, 12 strikes at 9 locations in the Republic of 
Serbia, 2 strikes at one location in the Republic of Montenegro and 98 strikes at 81 locations in Kosovo and Metohia.

In the south of Serbia, according to the data from the FRY Army, four areas in Serbia were confirmed with recorded radiological contamination. These are:

1. Pljačkovica Hill - about four kilometers north of Vranje, DU activity in soil samples $5.580-235.000(\mathrm{~Bq} / \mathrm{kg})$

2. Borovac - two locations southeast of Bujanovac for about six kilometers, DU activity in soil samples 250 - 17.490 (Bq / kg)

3. Bratoselce - northeast of Preševo for about $10 \mathrm{~km}$, the activity of DU in soil samples $1.800-23.400$ (Bq / kg)

4. Reljan - two locations, east of Presevo for about $10 \mathrm{~km}$, DU activity in soil samples $70-200(\mathrm{~Bq} / \mathrm{kg})$

The Pljačkovica hill top near Vranje where the relay station was located, was hit by a large number of DU rounds. The base of the hill is hard, rocky and made it possible for roundsto ignite and scatter radioactive aerosol over long distances (Anđelković-Lukić, 2015a).

There are bigger or smaller differences (depending on the source) between this and the data collected by the Army of the FR Yugoslavia, but it is important to note that a total of 49 strikes (or $44 \%$ ) of the DU ammunition attacks were carried out after the agreement had been reached to end the aggression, in the last 10 days of the war (Jovanović et al, 2012). Depleted uranium was used not only in $30 \mathrm{~mm}$ rounds but also in cruise missiles (with $300 \mathrm{~kg}$ stabilizer rods). It is no accident that Tomahawk cruise missiles are explicitly mentioned in the manual titled "KFOR International Brigades West / MNB-W / Depleted Uranium / Informatiom Book". They are used to destroy fortified concrete bunkers and underground hangars (Accame, 2006, p.15).

\section{Responsibility zone of the 125th Motorized Brigade}

The area of responsibility of the 125th Motorized Brigade is shown in Figure 1, marked in yellow. The combatants from the 125 Metohia Motorized Brigade and the protective battalion that was part of the brigade were exposed daily to heavy enemy fire. The task of the Defense Battalion of the 125 Motorized Brigade was to protect Klina, Dečani, Srbica, and Vučitrn from possible attacks by the paramilitary-terrorist KLA from the direction of Drenica, or the Čičavica mountain, where there was a large concentration of terrorist forces. In addition to protecting civilians, the task of the Defense Battalion of the 125 Motorized Brigade was to, in 
cooperation with the forces of the Serbian police, provide travel routes and convoys carrying food stuffs. During the war, the Brigade was in Metohia in the area of Kosovska Mitrovica, Drenica, Podujevo, Peć, Đakovica, and Klina.

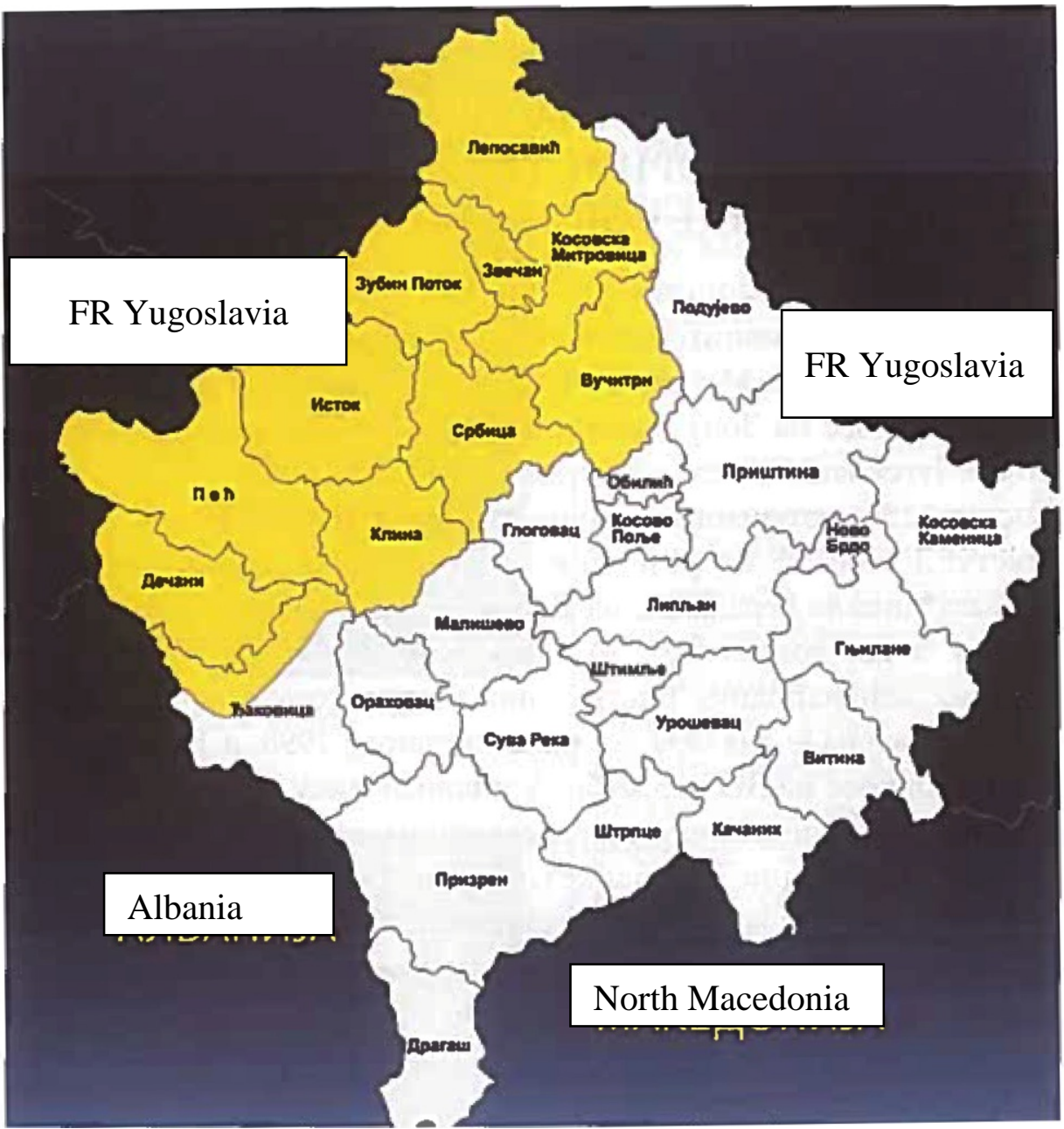

Figure 1 - Responsibility zone of the 125th Motorized Brigade (Đurović \& Petrušić, 2016, pp.137-138)

Puc. 1 - Зона ответственности 125-й моторизованной бригады (Đurović \& Petrušić, 2016, pp.137-138)

Слика 1 - Зона одговорности 125. моторизоване бригаде (Đurović \& Petrušić, 2016, pp.137-138) 
Figure 2 shows the sites in Kosovo and Metohia targeted by DU ammunition, according to the NATO map. It is clearly shown that not only the territory of Kosovo and Metohia was targeted but also the territory of North Macedonia and Albania.

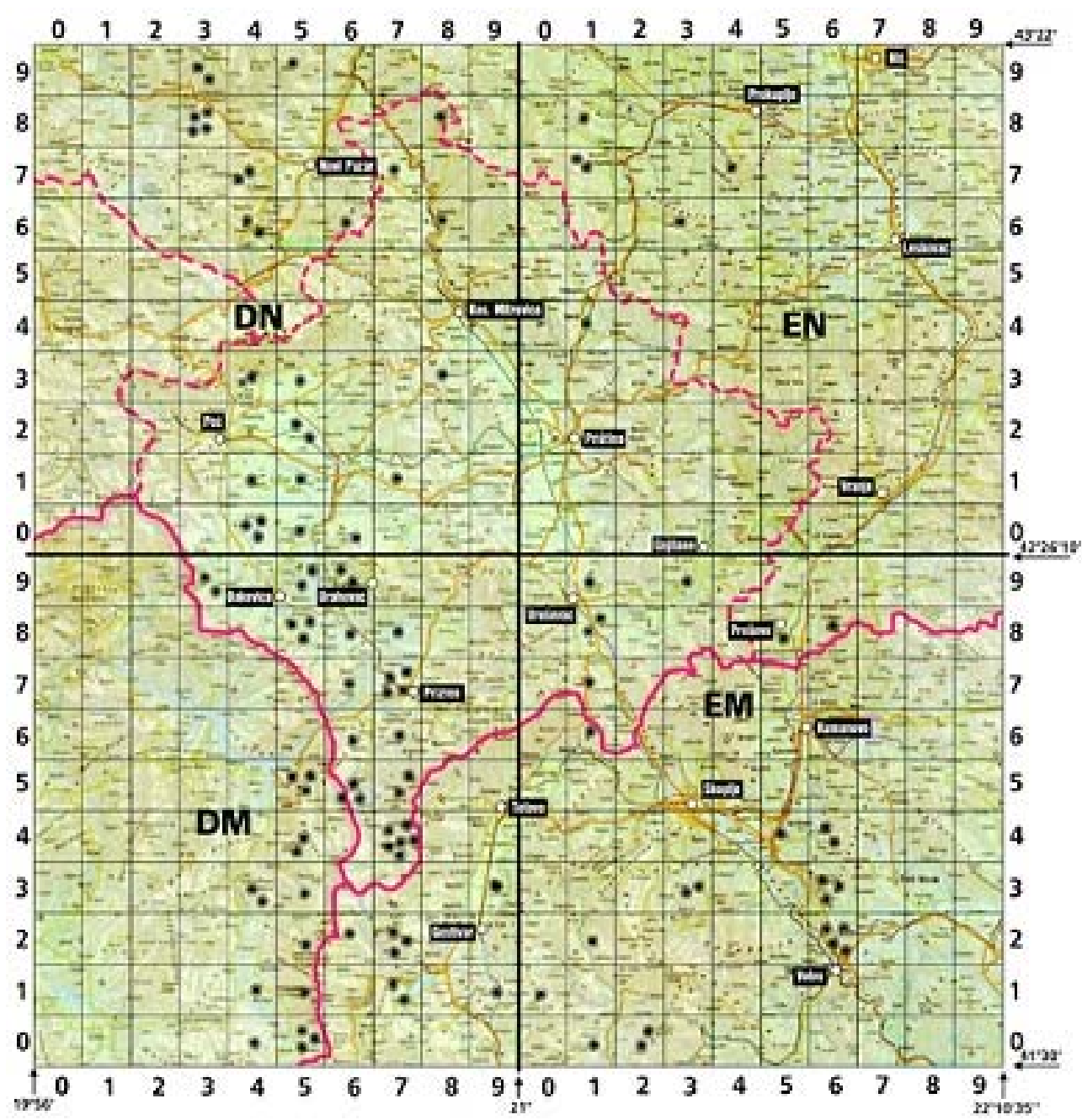

Figure 2 - Sites in Kosovo and Metohia that were targeted by DU ammunition based on NATO data (Ajdačić \& Jakšić, 2001, p.341)

Puс. 2 - Точки в Косово и Метохии, пораженные снарядами с обедененным ураном на основе документов HATO (Ajdačić \& Jakšić, 2001, p.341)

Слика 2 - Места на КиМ која су гађана муницијом са ОУ базирано на НАТО документима (Ajdačić \& Jakšić, 2001, p.341) 
Figure 3 illustrates the deployment of the KFOR (International Forces in Kosovo and Metohia) after the Kumanovo Agreement had been signed.

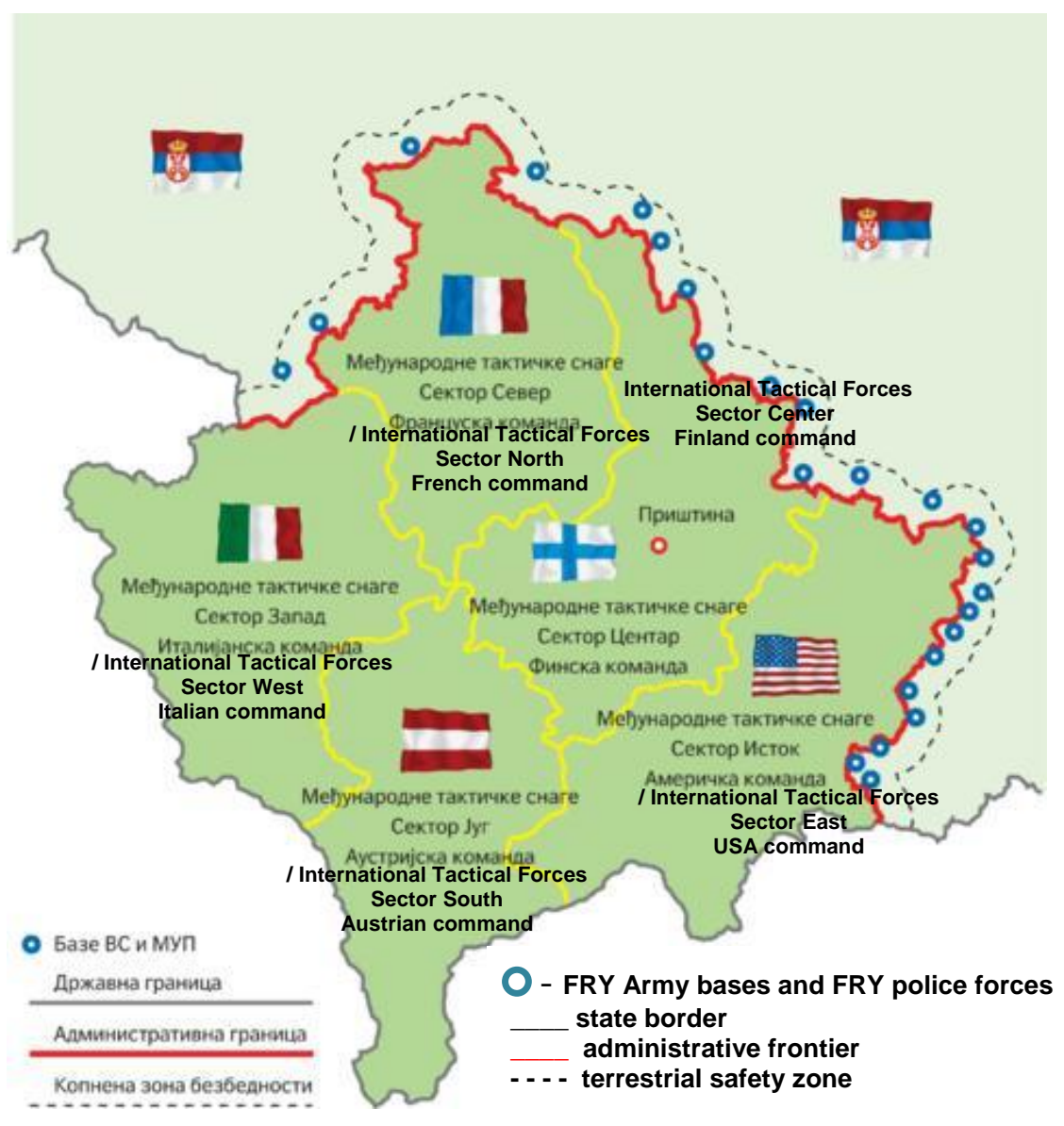

Figure 3 - Deployment of international forces after the signing of the Kumanovo Agreement (Ocić, 2019)

Puc. 3 - Дислокация международных сил после подписания Кумановского соглашения (Осіс́, 2019)

Слика 3 - Распоред међународних снага после потписивања Кумановског споразума (Ocić, 2019)

Figure 3 shows that the KFOR's Italian and French battalions were deployed in the area that was within the area of responsibility of the 125th Motorized Brigade. Some members of the KFOR international forces, soldiers from the Italian Battalion, fell ill with malignant tumours 
and many died after returning from Kosovo and Metohia. The surviving soldiers sued the Italian Ministry of Defense for failing to inform them of the health hazards they might encounter in the field and the case resulted in a verdict in their favour with adequate material compensation. The positive court decision also applied to those soldiers who died and had previously been in the wars in both Bosnia and Herzegovina and Kosovo and Metohia (Tagliazucchi \& Leggiero, 2019).

\section{Characteristics of the $30 \mathrm{~mm}$ DU round for a Gatling gun}

With its classic shape and appearance, the DU round belongs to sub-caliber ammunition that penetrates without explosive, due to its kinetic energy and mass, releasing high temperature.

It weighs about $727 \mathrm{~g}$ and consists of a cartridge case with initial and propulsion charges for ejecting a DU projectile. Inside an aluminium alloy casing, there is a DU core - cylindrical gray armour piercing penetrator with a dominant presence of ${ }^{238} \mathrm{U}$.

The core contains 2.2 grams of titanium. $95 \mathrm{~mm}$.

The diameter of the DU round penetrator is $16 \mathrm{~mm}$ and the length is $\mathrm{g} / \mathrm{cm} 3$.

The DU core weight is $298 \mathrm{~g}$ and the calculated density is 19.05

The total length of the DU projectile without a protective cap is 114 $\mathrm{mm}$.

Figure 4 shows a round fired in the FR Yugoslavia in 1999. The figure shows a complete DU round and a penetrator as well as a damaged round casing. The DU round kinetic energy of $157 \mathrm{~kJ}$ penetrates $60 \mathrm{~mm}$ thick armor at 500 meters and $38 \mathrm{~mm}$ thick armor at 1,000 meters. The nucleus is radioactive and emits 11,198 alpha and 35,914 low energy beta particles per second.

According to the report of the Nuclear Biological Chemical Defense Department Expert Group of the Army of Serbia and Montenegro HQ, the presence of alpha, beta and gamma radiation was determined by dosimetry measurements. The reports from April 23, 1999 and May 21, 1999 , of the Vinča Institute of Nuclear Sciences, among other things, stated: "Based on the results of gamma spectrometric measurements and the identification of radionuclides present, it can be claimed with certainty that the sample contains depleted uranium" (Jovanović et al, 2012, pp.37-41). 
In the case of touching apenetrator with bare hands,various pathogenic changes occur on the skinafter only 80 hours.

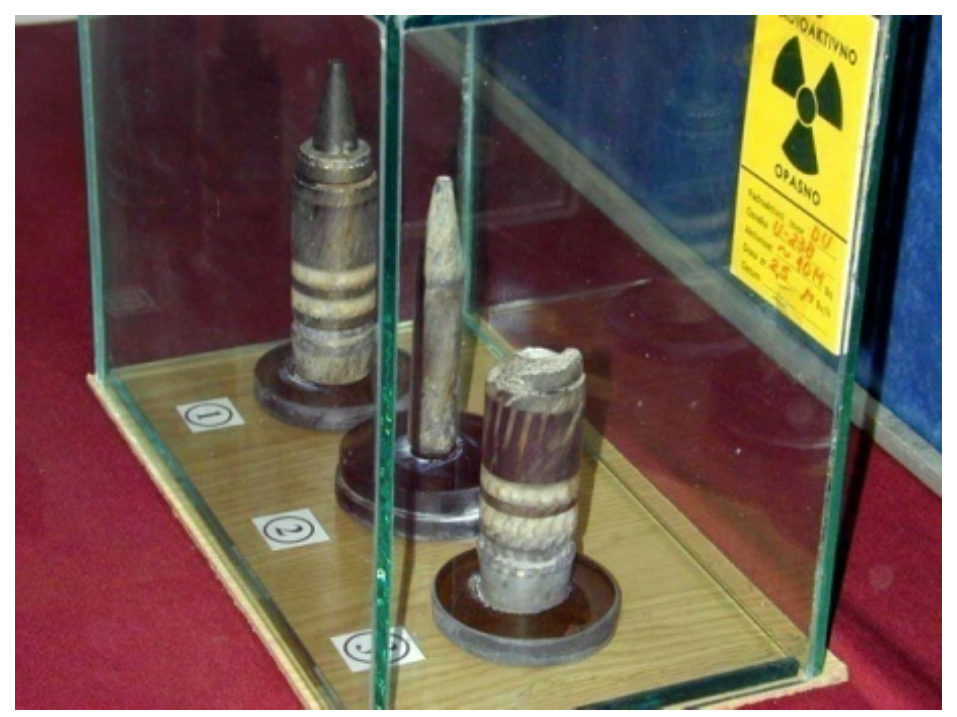

Figure 4-DU rounds used in the territories of the FR of Yugoslavia in 1999, exhibited at the Military Museum in Belgrade

Puc. 4 - Фотография снарядов с обедненным ураном, поразивших СР Югославию в 1999 году, выставлены в Военном музее в Белграде

Слика 4 - Метак са ОУ којим су гађани простори СР Југославије 1999. године, изложен у Војном музеју у Београду

\section{Functioning of a depleted uranium round after hitting a target}

Depleted uranium has the same chemical properties as natural uranium and is equally chemically toxic. Natural uranium has three isotopes: ${ }^{234} \mathrm{U},{ }^{235} \mathrm{U}$, and ${ }^{238} \mathrm{U}$. Their mass fraction in natural uranium is: $0.007 \%, 0.72 \%$, and $98.28 \%$, respectively. Only ${ }^{235} \mathrm{U}$ is used for nuclear power plants. ${ }^{235} \mathrm{U}$ is extracted from natural uranium to a content of $0.2-$ $0.3 \%$. and it is a by-product in the preparation of fuel for nuclear reactors and nuclear weapons.

Therefore, ${ }^{238} \mathrm{U}$ is uranium depleted in the ${ }^{235} \mathrm{U}$ content. Uranium is pyrophoric metal, easy to ignite and radioactive. Its external radioactivity is not significant, but the danger is high when inhaling or ingesting combustion products after a round has hit a hard target. 
When DU projectiles hit hard targets releasing high temperature, about $10 \%$ of the uranium penetrator burns into uranoxide and $70 \%$ goes into the aerosol state, the remainder being larger round fragments scattered around the impact site. When DU projectiles hit a hard ground or an armored vehicle, uranium, being easily flammable, ignites at about $700^{\circ} \mathrm{C}$ and develops a temperature of $3,000^{\circ} \mathrm{C}$, penetrating through the hardest armor, and with a small proportion of added plutonium, the temperature increases by another $400^{\circ} \mathrm{C}$ so that it reaches a combustion temperature of $3400^{\circ} \mathrm{C}$. After hitting a target, the round ignites and releases smoke-sized particles that burn in contact with the air causing short-term or long term damage to those who inhale them. The size of uranium aerosol particles is about $5 \mu \mathrm{m}$ and less, i.e. that of nanoparticles.

These particles contaminate the environment, can enter the body by inhalation or oral route, and depending on meteorological conditions, can be spread over long distances (40 to $300 \mathrm{~km}$ and beyond). Uranium oxides are toxic and partially soluble in water, so they can contaminate groundwater and reach thehuman food chain through plants (AnđelkovićLukić, 2015b, pp.39-50).

The 549th and 125th Motorized Brigades had tanks and armored fighting vehicles, which was a military objective for NATO aviation. In relation to the other parts of the Province, the area of Metohia was exposed to heavy NATO air strikes as it can be seen from Figure 2, and due to everyday bombing fromthe A-10 aircraft, there was high radioactivity on that front. According to the data of the FRY Army, the territory of Kosovo was targeted with 30-50 thousand DU projectileswhile 5,000 to 10,000 DU projectiles hit the locations outside the Province. In the 85 days during which the 125th Motorized Brigade was in Kosovo and Metohia, an average of 353 to 588 rounds were fired per day. The half-life of ${ }^{238} \mathrm{U}$ is $4.5 \times 10^{9}$ years (4.5 billion years). Analyses of the contaminated material samples from several Kosovo and Metohia sites revealed that the specific DU activity in individual samples ranged from several hundreds to $235,000 \mathrm{~Bq} / \mathrm{kg}$ per samples from Metohia, where was the 125th and 549th Motorized Brigades' area of responsibility. This is 1,100 times over the lower limit. For the purpose of calculation, the number of A-10 aircraft strikes was taken, where thecombat load for the $30 \mathrm{~mm}$ AN / GAU-8A Gatling gun is about 1100 to 1200 rounds, out of which about 880 rounds are with a DU core weighing about 300 grams. The natural background of uranium in soil is 5 to $125 \mathrm{~Bq} / \mathrm{kg}$ of soil. The most intense air strikes were in the Dečane, Uroševac and Đurakovac regions (Jovanović et al, 2012, p.56). 


\section{Health effects of increased radioactivity and the toxicity of depleted uranium and plutonium}

DU particles can enter the body by inhalation or with food and water. They are deposited for years in the lungs, kidneys (up to $12 \%$ of $\mathrm{DU}$ ), lymph glands, muscles, testicles, bones (up to $20 \%$ of DU), brain, liver, pancreas and spleen (up to $20 \%$ of DU). Regardless of the pathways of contamination of the body, these particles bind to the proteins and the erythrocyte membranein the blood, which is most damaging. After the war had ended, combatants who were in high-risk situations were invited for examinations. The greatest danger to human health is staying close to the target at the time of the hit. The medical check program lasted for 5 years and then was terminated. Over 1,500 members of the FRY Army were examined at three FRY Army establishments, but the program did not give the expected complete picture because the examined group was relatively small in relation to the number of exposed individuals, so that was not a representative sample (Đurović et al, 2011, pp.182-183).

The danger of DU is compounded by the fact that analyses of some projectile fragments have shown, in addition to DU, traces of americium, neptunium, technetium, and ${ }^{236} \mathrm{U}$ uranium. The UNEP teams that came to Kosovo and Metohia after the end of the war also detected the presence of plutonium, ${ }^{239} \mathrm{Pu}$, which increases the risk for humans. Its toxicity can be compared to that of cyanide and arsenic. When compared to toxicity, radioactivity is several thousand times higher, so plutonium dust of only 1 $\mathrm{mg}$ is enough to endanger a dozenof people inhaling it, and only $0.1 \mathrm{mg}$ is enough to cause cancer. Plutonium is a light-white metal with a density of $19.8 \mathrm{~g} / \mathrm{cm} 3$, with a half-life of 24,000 years, and it melts at about $639^{\circ} \mathrm{C}$. It is a dominant alpha emitter. It was used to produce the first atomic bomb, dropped on August 9, 1945, on Nagasaki (Jovanović et al, 2012, p.61).

The presence of plutonium increases the radiotoxicity of samples, which increases the risk for the exposed individuals. The main radiation doses of DU particles come from alpha and beta radiation, which is dangerous for human tissue even in small amounts, so if inhaled or ingested it would certainly give values over the permitted dose. Alpha radiation of DU particles causes significant primary direct radiation injury, mainly to tissues in direct contact with them, while beta and gamma radiation can damage other tissues as well. It is also collected in semen, where toxic and radiation effects lead to changes in genetic material resulting in numerous changes and processes: chromosomal 
aberrations, genetic mutations, genomic instability, cell inactivation or cell death (Đurović et al, 2011, pp.127-128).

\section{NATO indirectly acknowledges the dangers of depleted uranium particlesafter hittingan obstacle}

According to US sources and knowledge, radiological weapons with DU cause lasting effects on the population even after the end of hostilities, as DU particles contaminate soil and water for thousands of years to come. According to the resolution of the SubCommission on Prevention of Discrimination and Protection of Minoritiesof the UN Commission on Human Rights of 1996 and 1997, the use of these weapons of mass and nonselective destruction is against the norms of international humanitarian law. The first NATO member state, Belgium, despite having the NATO headquarters in Brussels, passed a law in 2009 to ban the production, storage, sale, transportation and use of depleted uranium weapons. The law came into force in mid-June 2009 (Vukmirović, 2019).

The members of the West Multinational Brigade upon KFOR's entry into the Kosovo and Metohia in November 1999 were given a nuclearchemical-biological manual entitled "KFOR International Brigade West / MNB-W / Depleted Uranium / Information Book". The manual was signed by Col Osvaldo Bizzari on 22 November 1999 and published in 2006 by retired NATO Admiral of the Mediterranean fleet, Falco Accame in his book Uranio impoverito. La verità/Depleted Uranium: The Truth (Accame, 2006). On the cover of the manual, besides the title, there is a skull which warns of radioactive danger. The manual was written as a warning of what type of danger the brigade members would face in the field and how to handle it. In the section called "The Golden Rules" it says: "Stay away from tanks, vehicles and buildings affected by missiles or cruise missiles with depleted uranium (DU). Wear a protective mask if you are operating within 500 meters of a tank or building hit by missiles or missiles with DU. Inhalation of insoluble uranium dust particles has long been associated with health consequences including cancer and neonatal deformities. These consequences can only be seen a few years later." In order to avoid contamination, soldiers are recommended, among other things, to wash their clothes frequently, and in the section entitled "Warning", among other things, it says: "Food and water will become unusable due to contamination with dust from DU. Do not eat food that is not controlled. When inhaled, particles can cause long-term damage." And the 
recommendations for dealing with the damaged or destroyed weapons of the Serbian army are the following:

"...Vehicles and materials of the Serbian army can be a danger to soldiers and civilians who come in close contact with them. Only qualified personnel must inspect destroyed or damaged vehicles and materials (....) and should absolutely avoid the proximity of vehicles suspected of being hit by a missile with DU. There should be no distance less than 50 meters. If you are forced to be closer, you must wear a protective mask and gloves to prevent uranium dust from entering your body."

This guide clearly confirms the fact that before the start of the bombing of FR Yugoslavia, NATO and the USA knew that weapons with DU were dangerous, carcinogenic and genotoxic; however, despite knowing what kind of dangerous weapons they had, they used them in the territory of Serbia. They knew that such irradiation of air, land, and water would certainly have far-reaching consequences for human health and their offspring. They warned their own members of the danger, while the civilian population was never warned of the dangers - on the contrary, they are still publicly claiming that there is no danger of DU particles.

The Manual refers to objects "hit by missiles or cruise missiles with $D U$ " which clearly indicates that NATO Pact forces in Kosovo and Metohia and elsewhere in Serbia also used cruise missiles with DU. The US military regulations in the field of radiation protection require every soldier wear a protective suit during training and wear a protective mask for any activity within 20 - 50 meters of an object struck by ammunition with DU (Accame, 2006, pp.8-11). The danger of radioactive dust from DU particles in the United States has long been known. Thus, a US military document emphasized the dangers of DU: "The major danger associated with depleted uranium is the harmful effect it can have if it enters the body. If the particles are inhaled or ingested, they can be chemically toxic and cause considerable and long-lasting irradiation of the internal tissues." (Anđelković-Lukić, 2015a, pp.225-226)

During the aggression, the members of the FRY Army in Kosovo and Metohia did not wear protective suits or masks, so the likelihood that they could inhale or swallow radioactive particles from uranium dust generated by the combustion of DU munition was VERY HIGH.

In the immediate aftermath of the war, many works and professional conferences were dedicated to this military conflict. In 1999, the complete issue No 12 of the French journal "Défense nationale" was dedicated to the war in Kosovo and Metohia and in the conference presentation entitled "First lessons from the war in Kosovo"(Les premières leçons de 
la guerre au Kosovo") there is the following statement: "After the end of the Kosovo War, historians will give their judgment in a few months or years, but it can already be said that there was no capitulation of the Serbian army or the Serbian state; television has confirmed this in the best sense. Some regret it, but it's true." (David, 1999, p.39).

\section{Conclusion}

After the aggression had ended, mortality among veterans from Kosovo and Metohia increased. Many soldiers who were not injured in the war died from radiation received in Kosovo and Metohia, so that the death toll during the war subsequently increased by the number of deaths from various types of malignancies. Unfortunately, today, nothing seems to be done in Serbia to investigate and prove the damage caused by the bombing, thus denying the dominant effects of depleted uranium and chemical agents on cancer growth in Serbia.

There is no centralized statistics to accompany the increase in the number of people suffering from malignancies among members of the military and police who were deployed in Kosovo and Metohia. The radiation in Kosovo and Metohia was high during the aggression, in some cases as much as 1,100 times that of the natural background.

\section{References}

Accame, F. 2006. Uranio impoverito. La verità. Rome, Italy: Malatempora (in Italian). ISBN 8884250366.

Ajdačić, V. \& Jakšić, P. 2001. Search for the truth about the NATO use of depleted uranium in the war against Yugoslavia - truth under the DU carpet. In: ENRY2001-International Conference on Environmental Recovery of Yugoslavia, Belgrade, pp.338-342. September 27-30 [online]. Available at: https://inis.iaea.org/collection/NCLCollectionStore/_Public/34/047/34047646.pdf ? $r=1 \& r=1$ [Accessed: 15 March 2020].

Anđelković-Lukić, M. 2015a. Darovi milosrdnog anđela - Ekološko razmatranje rata NATO protiv SR Jugoslavije, 2. dopunjeno izdanje. Novi Sad: Balkanija (in Serbian).

Anđelković-Lukić, M. 2015b. Chemical, Radiological and Environmental Impacts of NATO's War of Aggression against Yugoslavia. In: $19^{\text {th }}$ Internacional Scientific Eco-Conference, Novi Sad, Serbia, pp.39-50, 23-25 September.

David, D. 1999. Kosovo: de vraies et de fausses leçons stratégiques. Revue Défense Nationale, 615(Decembre), pp.39-43 (in French) [online]. Available at: https://www.defnat.com/e-RDN/vue-article.php?carticle=7517 [Accessed: 15 March 2020]. 
lić, B 2019. NATO je na Srbiju bacio 20 puta više uranijuma nego što priznaje. Novi standard, 30 July [online]. Available at: https://www.standard.rs/2019/07/30/delic-nato-je-na-srbiju-bacio-20-puta-viseuranijuma-nego-sto-priznaje/ (in Serbian) [Accessed: 15March 2020].

Đurović, S., \& Petrušić, J. 2016. Zašto ćutiš Srbijo. Belgrade: Svesrpski otadžbinski tabor (in Serbian).

Đurović, B., Spasić-Jokić, V., Petković, S., Fortuna, D., SelakovićMićunović, V., \& Atlagić, N. 2011. Osiromašeni uranijum - metode detekcije, saniranje neposrednih efekata i prevencija kasnih posledica. Belgrade: doc. dr Branka Đurović (private publisher - personal edition).

Jovanović, V., Petković, S., \& Čikarić, S. 2012. Zločin u ratu - genocid u miru: posledice NATO bombardovanja Srbije 1999. godine. Belgrade: Službeni glasnik (in Serbian).

Ocić, Č. 2019. Katastrofalne posledice zapadne politike prema Kosovu i Metohiji. Koreni, 27 May [online]. Available at: http://www.koreni.rs/katastrofalneposledice-zapadne-politike-prema-kosovu-i-metohiji/ (in Serbian) [Accessed: 15 March 2020].

Tagliazucchi, M.,\& Leggiero, D. 2019. Militari all'uranio. Per la prima volta $i$ retroscena svelati da testimonianze, documentazioni e foto. Serrungarina, Pesaro Urbino, Italy: David and Matthaus (in Italian).

Vukmirović, Z. 2019. Osiromašeni uranijum je zabranjen u Belgiji 2009. godine. Politika 20 April [online]. Available http://www.politika.rs/scc/clanak/427470/Pogledi/Osiromaseni-uranijum-jezabranjen-u-Belgiji-2009-godine (in Serbian) [Accessed: 15 March 2020].

\section{РАДИАЦИОННОЕ ОБЛУЧЕНИЕ ВОЕННОСЛУЖАЩИХ СР ЮГОСЛАВИЯ В КОСОВО И МЕТОХИИ ВО ВРЕМЯ АГРЕССИИ НАТО В 1999 ГОДУ}

Мирьяна Н. Анджелкович-Лукич

Военно-технический институт, г. Белград, Республика Сербия; Правительство Республики Сербия, Межведомственный координационный орган, г. Белград, Республика Сербия

РУБРИКА ГРНТИ: 78.00.00 ВОЕННОЕ ДЕЛО;

78.25.12 Химическое, биологическое и ядерное оружие. Средства защиты от оружия массового поражения 61.00.00 ХИМИЧЕСКАЯ ТЕХНОЛОГИЯ. ХИМИЧЕСКАЯ ПРОМЫШЛЕННОСТЬ; 61.01.94 Охрана окружающей среды

ВИД СТАТЬИ: обзорная статья ЯЗЫК СТАТЬИ: английский 
Резюме:

Введение/цель: В данной статье приведены данные о стадиях облучения, которому подвергались военнослужащие армии Союзной Республики Югославия и особенно члены моторизованных бригад в районе Косово и Метохии на албанско-югославской границе.

Методы: С помощью гамма-спектра было выявлено, что снаряды содержали обедненный уран, а наличие альфра, бета и гамма излучений было определено методом дозиметрических измерений.

Результаты: Использование боеприпасов с обедненным ураном

${ }^{238} \mathrm{U}$, к которому добавлен плутоний, наносит долгосрочный ущерб окружающей среде, в виде заражения воды и почвы, вызывая различные расстройства и злокачественные заболевания у людей. Радиоактивность ${ }^{239} \mathrm{Pu}$ в несколько тысяч раз превышает его токсичность, а вдыхание плутониевой пыли ставит под угрозу здоровье и вызывает рак. Уран является токсичным пирофоорным металлом, легко воспламеняющимся и радиоактивным. Его оксиды токсичны и частично растворимы в воде. Во время взрыва снаряда освобождаются радиоактивные аэрозольные частицы в виде дыма, которые воспламеняются при взаимодействии с воздухом, вызывая кратковременные или долговременные повреждения у вдыхающих. Во время агрессии НАТО против СР Югославия при измерениях на территории Косово и Метохии был выявлен высочайший уровень радиации. $B$ районе Метохии радиоактивность была в 1100 раз выше естественного радиационного фона.

Выводы: Выявлено, что во время войны военнослужащие армии СР Югославии подвергались воздействию высоких радиоактивных доз, вследствие этого количество различных злокачественных новообразований и смертельных исходов возросло в несколько раз.

Ключевые слова: химическая война, снаряды с обедненным ураном, повышенная радиоактивность, гемотоксичность, плутоний, радиактивное заражение военнослужащих армии Союзной Республики Югославия, болезни, злокачественные опухоли. КОСОВУ И МЕТОХИЈИ У ТОКУ НАТО АГРЕСИЈЕ 1999. ГОДИНЕ

Мирјана Н. Анђелковић Лукић

Војнотехнички институт, Београд, Република Србија;

Влада Републике Србије, Међуресорно координационо тело,

Београд, Република Србија 
ОБЛАСТ: хемијске технологије ВРСТА ЧЛАНКА: стручни рад ЈЕЗИКЧЛАНКА: енглески

\section{Сажетак:}

Увод/циљ: У раду се указује на дозу озрачености којој су били изложени припадници Војске СР Југославије, а посебно припадници моторизованих бригада на подручју Косова и Метохије на албанско-југословенској граници.

Mетоде: Гамаспектрометријским мерењима утврђено је да пенетратор у метку садржи осиромашени уранијум, а методом дозиметријског мерења утврђено је присуство алфра, бета и гама зрачење.

Резултати: Употреба муниције са осиромашеним уранијумом ${ }^{238} \mathrm{U}$, коме је додат и плутонијум, на дуаи рок загађује околину, воду и земљиште, а код људи изазива различите поремећаје и болести, пре свега малигне. Радиоактивност ${ }^{239} \mathrm{Pu}$ је неколико хиљада пута већа од његове токсичности, а удисање плутонијумске прашине угрожава здравље и изазива канцер. Уранијум је пирофроран токсичан метал, лако се пали и радиоактиван је. Његови оксиди су отровни и делимично растворљиви у води. После паљења метак ослобађа радиоактивне аеросолне честице димензије дима, које сагоревају у додиру са ваздухом, изазивајући код онога ко их удахне краткотрајна или дуготрајна оштећења. За време агресије HATO-а на СР Југославију на Косову и Метохији је измерена велика радиоактивност. У метохијском подручју она је била 1100 пута већа од природног фонна.

Закључак: Припадници Војске СР Југославије су током рата били изложени великим радиоактивним дозама, што је довело до повећаног оболевања од разних малигних болести и смртних uсхода.

Кључне речи: хемијски рат, муниција од осиромашеног уранијума, повећана радиоактивност, хемотоксичност, плутонијум, озраченост припадника Војске СР Југославије, болести, малигнитет.

Paper received on / Дата получения работы / Датум пријема чланка: 12.03.2020. Manuscript corrections submitted on / Дата получения исправленной версии работы / Датум достављања исправки рукописа: 18.03.2020.

Paper accepted for publishingon / Дата окончательного согласования работы / Датум коначног прихватања чланка за објављивање: 20.03.2020. 
(c) 2020 The Author. Published by Vojnotehnički glasnik / Military Technical Courier (www.vtg.mod.gov.rs, втг.мо.упр.срб). This article is an open access article distributed under the terms and conditions of the Creative Commons Attribution license (http://creativecommons.org/licenses/by/3.0/rs/)

(c) 2020 Автор. Опубликовано в «Военно-технический вестник / Vojnotehnički glasnik / Military Technical Courier» (www.vtg.mod.gov.rs, втг.мо.упр.срб). Данная статья в открытом доступе и распространяется в соответствии с лицензией «Creative Commons» (http://creativecommons.org/licenses/by/3.0/rs/)

(C) 2020 Аутор. Објавио Војнотехнички гласник / Vojnotehničkiglasnik / MilitaryTechnical Courier (www.vtg.mod.gov.rs, втг.мо.упр.срб). Ово је чланак отвореног приступа и дистрибуира се у складу са Creative Commons licencom (http://creativecommons.org/licenses/by/3.0/rs/). 